\title{
Implementation of Project Based Learning on Student Reasoning on Covid-19 Disaster Mitigation
}

\section{*Kiki Septaria, Binar Ayu Dewanti}

\author{
Science Education Department, Faculty of Teacher Training and Education, Universitas
} Islam Lamongan. Jl. Veteran No. 53A, Lamongan, Indonesia. Postal code: 62213

*Corresponding Author e-mail: kikiseptaria@unisla.ac.id

Received: September 2020; Revised: April 2021; Published: June 2021

\begin{abstract}
Disaster mitigation is activity that very important to teach and learning to someone as early as possible. Disaster mitigation can teach through positive activities such as school learning. This research aims to describe the implementation of Project Based Learning on students' reasoning for Class VII Covid-19 Disaster Mitigation at SMP 1 Maduran. This research is very much needed to see students' reasoning for understanding the concept of Covid-19 disaster mitigation and to train Covid-19 disaster preparedness as early as possible for students of SMPN 1 Maduran. Data of this research ware collected from 30 students of grade VII at SMPN 1 Maduran. The finding reveal the The findings from this research were that problem-based and project-based learning was able to significantly improve students' mitigation reasoning, especially on the topic of the Covid-19 disaster at SMPN 1 Maduran students. Based on these findings, it is hoped that covid-19 disaster education and other disasters can be educated to students with project-based learning and problem solving.
\end{abstract}

Keywords: Disaster mitigation; Project Based Learning; Covid-19; Students Reasoning

How to Cite: Septaria, K., \& Dewanti, B. (2021). Implementation of Project Based Learning on Student Reasoning on Covid-19 Disaster Mitigation. Prisma Sains : Jurnal Pengkajian Ilmu dan Pembelajaran Matematika dan IPA IKIP Mataram, 9(1), 20-27. doi:https://doi.org/10.33394/j-ps.v9i1.2951

\section{INTRODUCTION}

Reasoning ability is one of the goals in learning, namely to train how to think and reason in drawing conclusions, develop problem-solving skills, and develop the ability to convey information or communicate ideas through oral, written, pictures, graphics, maps, diagrams, and so on (Prastiwi, 2019; Fatharani, 2019). Reasoning is very important for someone to help solve based on logic and find ways to solve very complex problems (Handayani, 2020). Reasoning abilities need to be trained on someone as early as possible for someone, in order to maximize one's ability to solve problems (Khoeriyah \& Ahmad, 2020). Reasoning abilities can be taught starting from students at the junior high school level in various ways used by educators, one of which is through the selected learning model.

The learning model to practice student reasoning is a student-centered learning model (Mazfufah, 2017). Student-centered learning models prepared ample chance for students to move to learn learning topics (Munir, 2019). Various kinds of student-centered learning models were developed to facilitate students in learning, one of which is the project-based learning model (Nurmaliyani, 2018). Through project-based learning, students required to increased their thinking and communication skills in solving problems given in the project by using their reasoning.

The project-based learning model displays a phenomenon that occurs in the surrounding environment to find possible problems, this helps train students' reasoning in honing their reasoning skills (Ntelok et al, 2018). In addition to improving students' reasoning 
skills, the project-based learning model also encourages students to help solve problems experienced in the community, so that the benefits of learning are not only felt by students but also by the community (Permatasari, 2019). reasoning is very important until an international institution, namely TIMSS, conducts reasoning assessments on students in various countries in the world including Indonesia. The results of the measurement from TIMSS stated that the reasoning of students in Indonesia was very weak and even got the lowest ranks from countries where the students' reasoning was measured. (Ministry of Education and Culture, 2019). Apart from TIMSS, there is also a Program for International Student Assessment (PISA) which is an assessment to test the academic performance of school children. The tests measured in PISA are in the areas of problem solving, reasoning and communication skills. Between PISA and TIMSS, the aspects measured in both are aspects of reasoning, thus showing that students' reasoning abilities are the criteria needed in the learning assessment process (Fatharani, 2019).

The science learning process requires reasoning skills so that students can smartly and synchronize their scientific knowing with natural phenomena that occur around them. Reasoning is also needed in making decisions or solving problems in everyday life (Soleh, 2018; Sundria, 2019). There is a relationship between students 'learning abilities and their reasoning abilities, namely the higher the students' learning abilities, the higher the students 'ability to reason, while the lower the students' learning abilities, the worse their reasoning abilities will be (Rahayu, 2017; Yulianti, 2020).

Referring to previous research that examined project-based learning models related to student reasoning, it was stated that project-based learning models can increase student activity during learning by up to $74 \%$ so that student reasoning also increases (Prastiwi, 2018). The reasoning of students can also be improved significantly if it involves students in solving problems that are around them (Shofiyah, 2018). Project-based learning is a model used to train students to solve various problems they face independently or in groups (Septaria, 2019). Giving problems in learning is able to hone students' reasoning power by analyzing the causes and effects caused and how to solve these problems.

The results of pre-research conducted on class VII-1 students at SMPN 1 Maduran obtained a percentage of $58.2 \%$ for students' reasoning abilities. The finding of preleminary study can be concluded that the reasoning ability of grade VII-1 students at SMPN 1 Maduran is lack. This is means the researcher's observations that provide a stimulus in the form of inviting students to reason, but student's are still difficult to apply reasoning and do not get the expected answers. In addition science teachers interviews at SMPN 1 Maduran, it was stated that the learning methods used were still dominated by conventional methods, namely the lecture and question and answer methods. The lecture method does not make students develop and prevent students from exploring further. The teacher said that the lecture method was the easiest method to do and was considered more capable of conveying the aims and objectives of learning to students. But in reality, students are bored with the method and often ignore the teacher who is explaining because it is considered monotonous. So that from the results of the pre-research above, it is deemed necessary to use other methods of learning to hone students' reasoning powers, one of which is the project based learning model. Researchers have a desire to improve and optimize by conducting research on the application of fun learning using project-based learning to mitigate the ongoing covid19 disaster.

\section{METHOD}

This Research uses one class (30 students) as research subjects and will receive pre-test prior to treatment and after the researchers will do a post-test to measure the results of special treatment researchers. In simple terms it can be illustrated in the following chart. 


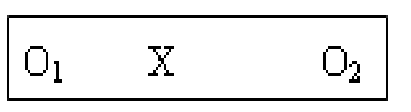

$$
\begin{aligned}
& \mathrm{O}_{1}=\text { pre-test } \\
& \mathrm{O}_{2}=\text { Post-test } \\
& \mathrm{X}=\text { Treatment Using Project Base Learning }
\end{aligned}
$$

Students who are the subject of research are recommended from SMPN 1 Maduran. SMPN 1 Maduran is one of the junior high schools owned by the government with accreditation A, so this school is suitable for use as a place for conducting research. A total of 30 students with a gender ratio of $60 \%$ girls and $40 \%$ boys who belong to class VII A. The ability of students' reasoning data is obtained based on the results of the initial test (pre-test) and the final test (post-test), this data can also be used to analyze the researcher's treatment in the form of project-based learning whether it is successful or not in improving student reasoning. The supporting data used by researchers is the cognitive test results from the sample. The Students reasoning ability indicators used in this study are (1) explaining the relationship between the elements in the problem, (2) creating a problem-solving project structure, and (3) realizing the project that has been designed in the form problem solving results. The test method was chosen by the researcher to measure students' reasoning because it was considered the most suitable method to be used.

Measurement of students' reasoning abilities was carried out using scoring with a maximum value range of 100 accumulated for each question. The criteria for students' reasoning ability are calculated based on whether or not there is an increase experienced by students after participating in learning. The researcher chose the N-Gain calculation to determine the increase in students' reasoning, using the formula:

$$
\begin{aligned}
& \text { Student score }=\frac{\text { Acquisition score }}{\text { Maximum score }} \times 100 \\
& <g>=\frac{\text { posttest }- \text { pretest }}{100-\text { pretest }}
\end{aligned}
$$

Furthermore, calculations will be carried out using this equation, the scores obtained by students will be converted by adjusting the following criteria:

Table 1. Criteria for N-Gain Score

\begin{tabular}{ll}
\hline Score & Criteria \\
\hline $0.0<\mathrm{g} \leq 0.3$ & Low \\
$0.3<\mathrm{g} \leq 0.7$ & Medium \\
$0.7<\mathrm{g} \leq 1.0$ & High \\
\hline
\end{tabular}

Using the N-gain criteria above, the special treatment of researchers in the form of preprepared learning on the Covid-19 Disaster Mitigation is said to be successful if student learning outcomes get a score of $0.0<(<\mathrm{g}>) \leq 1,0$.

\section{RESULTS AND DISCUSSION}

This present research was designed to measure students' reasoning in science subjects on the topic of covid-19 disaster mitigation at SMP Negeri 1 Maduran. Describing in the preeleminary study data there is a lack of learning tools to support fun learning and improve students' reasoning on the topic of disaster mitigation even though they have a fairly high minimum passing standard of 75 . The researcher then developed a cognitive test in the form of an essay of 3 questions along with a rubric for measure student reasoning

Project Based Learning implementation can develop students' reasoning skills through learning projects that are applied during the learning process. Projects given to students are projects that focus on students' thinking processes so that students can use their reasoning power well. The results of the comparison analysis of the preliminary and final test data 
showed a significant difference in scores with the direction of increasing students' reasoning abilities. Covid-19 disaster mitigation can be rationalized by students using predefined projects in learning. The final result of reasoning is compared with the minimum completeness of each student, which is a score of 75 with the following results (Table 2).

Table 2. Gain Analysis for Each Indicator

\begin{tabular}{|c|c|c|c|c|}
\hline Indicator & Pretest & Posttest & NGain & Category \\
\hline $\begin{array}{l}\text { 1. Explaining the Relationships between the } \\
\text { Elements in the Problem }\end{array}$ & 48 & 78 & 0,58 & Medium \\
\hline 2. Create a Problem Solving Project Structure & 46 & 87 & 0,76 & High \\
\hline $\begin{array}{l}\text { 3. Realizing Projects That Have Been Designed } \\
\text { In The Form Of Problem Solving Results }\end{array}$ & 55 & 85 & 0,67 & Medium \\
\hline
\end{tabular}

After the gain test is carried out on each indicator, then a gain test is carried out on each student who is the research subject. the results of the Gain calculation for each student can be seen in Table 3 below.

Table 3. Analysis of Student Reasoning Pretest-Posttest Results

\begin{tabular}{|c|c|c|c|c|c|c|c|c|c|}
\hline \multirow{2}{*}{ Student } & \multicolumn{2}{|c|}{ Score } & \multirow{2}{*}{ NGain } & \multirow{2}{*}{ Category } & \multirow{2}{*}{ Student } & \multicolumn{2}{|c|}{ Score } & \multirow{2}{*}{ NGain } & \multirow[t]{2}{*}{ Category } \\
\hline & Pretest & Posttest & & & & Pretest & Posttest & & \\
\hline $\mathrm{S} 1$ & 45 & 75 & 0,55 & Medium & S16 & 35 & 55 & 0,31 & Medium \\
\hline $\mathrm{S} 2$ & 50 & 90 & 0,80 & High & S17 & 55 & 95 & 0,89 & High \\
\hline S3 & 45 & 80 & 0,64 & Medium & S18 & 70 & 95 & 0,83 & High \\
\hline $\mathrm{S} 4$ & 55 & 95 & 0,89 & High & S19 & 50 & 95 & 0,90 & High \\
\hline S5 & 40 & 85 & 0,75 & High & $\mathrm{S} 20$ & 60 & 100 & 1,00 & High \\
\hline S6 & 75 & 90 & 0,60 & Medium & $\mathrm{S} 21$ & 70 & 85 & 0,50 & Medium \\
\hline $\mathrm{S} 7$ & 60 & 90 & 0,75 & High & $\mathrm{S} 22$ & 35 & 55 & 0,31 & Medium \\
\hline S8 & 45 & 70 & 0,45 & Medium & $\mathrm{S} 23$ & 70 & 100 & 1,00 & High \\
\hline S9 & 60 & 90 & 0,75 & High & $\mathrm{S} 24$ & 45 & 80 & 0,64 & Medium \\
\hline $\mathrm{S} 10$ & 60 & 80 & 0,50 & Medium & $\mathrm{S} 25$ & 75 & 80 & 0,20 & Low \\
\hline $\mathrm{S} 11$ & 60 & 95 & 0,88 & High & $\mathrm{S} 26$ & 90 & 95 & 0,50 & Medium \\
\hline $\mathrm{S} 12$ & 70 & 95 & 0,83 & High & $\mathrm{S} 27$ & 60 & 100 & 1,00 & High \\
\hline S13 & 45 & 70 & 0,45 & Medium & $\mathrm{S} 28$ & 50 & 95 & 0,90 & High \\
\hline S14 & 70 & 85 & 0,50 & Medium & S29 & 70 & 100 & 1,00 & High \\
\hline S15 & 60 & 85 & 0,63 & Medium & S30 & 45 & 70 & 0,45 & Medium \\
\hline
\end{tabular}

Value obtained from the student completeness analysis, of the 30 students who took the initial test (pre-test), was 27 students. those who have not met the minimum completeness while 3 students are declared complete because they get a score above the minimum completeness, there are even students who get a score of 90 out of 100 . The finding of this initial test (pretest) showed students' reasoning at school was still low and not well honed, so it was necessary learning model that fits and is able to help students develop their reasoning skills. The learning model that can be used is Project Based Learning which aims to train students' reasoning on Covid-19 Disaster Mitigation material. 
The findings of the initial assessment results of class VII-A students obtained an NGain score of 0.58 with a moderate increase in the reasoning indicator, namely linking the relationship between problem elements. Students are systematically able to show increased reasoning abilities by connecting problems with fields of science that have been studied such as covid-19 disaster mitigation linked to students' knowledge of viruses, micro-organisms, acids and bases, addictive substances / additives and health. When the topic of Covid-19 disaster mitigation is taught in a lesson, of course, it has various disciplines according to the point of view used by the teacher (Rahayu, 2017). Learning the topic of covid-19 can be taught from a disaster mitigation perspective, namely prevention and education of the dangers of covid-19 so as not to participate in being infected, handling when covid-19 infection occurs and after being infected.

The indicator links the relationship between elements of the Covid-19 disaster mitigation problem when compared to other student reasoning indicators which are relatively lower, this is because it is possible that students have lack literacy from various sciences related to Covid-19. The weakness of the ability to relate relevant knowledge to covid-19 can be caused by various things such as students not being able to identify the root of the problem from covid-19 that is happening, students have not been able to calculate and plan the steps needed in observing to make conclusions from the observations that have been made and students have not been able to identify the diversity of dimensions or points of view of Covid-19. Not all students have problems linking covid-19 with multi-disciplinary disciplines, but students need literacy and experience that may vary between students (Bransford, 1984).

The ability to relate relevant knowledge is very important to teach students to increase knowledge, viewpoints on learning topics, increase learning motivation which is needed by every student. Usually the ability to associate learning topics with related multi-disciplinary disciplines can be trained in the perception of learning or early learning activities.

After receiving research treatment, the final assessment is carried out on the indicator linking the topic relationship with other disciplines which are found to have increased, this can happen when the teacher train and guide students in stages starting from identifying the elements contained in the topic of disaster mitigation, linking each element with one and more complex disciplines, this is because the Project Based Learning learning model makes students the center of learning so that the learning process becomes two-way between teachers and students. The Project Based Learning model makes teachers actively participate in learning to help students who experience difficulties.

The second indicator is creating a problem solving project structure, where the gain is 0.76 in the high category. In this second indicator students are asked to make a structured design in solving the problems given. Students make an agreement about the rules in making projects. Matters that were agreed upon, among others: selection of activities, time for project completion, things to be reported, as well as limitations in project development. $\mathrm{n}$ the reasoning indicator, identifying and making solutions to the problem of the Covid-19 disaster challenges students to provide solutions based on their cognitive abilities, imagination and creativity to reduce the negative impact of Covid-19. The finding of solutions found by students must be based on the knowledge, creativity, imagination, experience, and theories possessed by these students so that it is very possible for each student to have unique and different solution ideas.

The findings of the increase in the ability to structure student problem-solving projects increased very significantly because the teacher trained in great detail the topic of covid-19 mitigation, the covid-19 phenomenon is happening in student life and the learning model used by the teacher is fun and meaningful for students, so that students can construct their understanding of the Covid-19 Disaster Mitigation material by means of reasoned. Increasing the ability of students to make problem solutions begins with the enthusiasm of students in learning, starting from the questions asked by students during apperception, student activities 
in conducting simple experiments and in the closing process of learning. The results of the observations of researchers as many as $92 \%$ of students in active learning were able to design, follow step by step investigating the Covid-19 problem and identify the results of the investigation, while $90 \%$ of students were able to find the core problem of the ongoing Covid-19 disaster. High student activity can also indicate that students have more motivation in the learning covid-19 disaster mitigation, where this motivation supports students in being creative. According to Thomas L. Good and Jere B. Braphy (2010) that motivation is a driving and driving energy, which can strengthen and encourage someone to behave. Based on these definitions, it can be seen that someone does something depending on their motivation.

The increase in gain on this second indicator gets a high category. This shows that students have succeeded in improving their reasoning in structuring problem-solving projects. Killpatrick and Findell (2001) suggest that new knowledge possessed by students is based on the experience and knowledge that existed before students received certain treatment. This particular treatment can add new experiences and stimulate students' reasoning in analyzing a certain phenomenon that is presented.

The last $\left(3^{\text {th }}\right)$ indicator is the realization of a project that has been designed in the form of problem solving results which have a gain score of 0.67 with medium category. In this third indicator, students carry out activities that have been planned and then realize the project that will be made in solving the problems given in the form of demonstrations in front of the class. After the demonstration is carried out, students will be asked to conclude the results of the projects that have been made whether they can solve the existing problems. Students will have the skills to conclude a problem or the results of observations from a phenomenon when students are able to make correlations and have broad knowledge literacy from various perspectives of the knowledge they have. Correlation skills and multidisciplinary knowledge literacy can be trained by teachers in a well-structured lesson from perception to learning closure according to the topic or problem discussed in a lesson (Rahayu, 2017).

At the end of the research, students received a questionnaire to measure the accuracy of the projects that had been planned and made during the covid-19 disaster mitigation learning, it was found that $95 \%$ of students stated that the project was made according to the plan that had been made. The level of suitability between the project design and the realization of manufacturing can be used as a basis for students to be able to identify the root of the Covid19 problem, find possible solutions, design and apply step-by-step solutions to help solve the problem of the Covid-19 disaster. Learning experiences carried out by students themselves are activities that can be recorded by the brain and entered into long-term memory, so that students will not easily forget cognitively and psychomotor in reducing the negative impact of the Covid-19 disaster. The results of the research findings of researchers support Handayani's research (2015) where students need to get learning that can be experienced and carried out by students directly in order to increase student experience and skills, so it is hoped that student learning achievement can increase significantly. The findings on student activities during project creation to solve the Covid-19 problem lie in $92 \%$ which shows students individually or in a group working together, helping each other to design and complete planned projects.

The findings of the research treatment in the form of project-based learning in class VII-A at SMPN 1 Maduran with the topic of covid-19 disaster mitigation were able to improve students' reasoning abilities well. The increase in students' reasoning abilities was seen in the three reasoning indicators that increased after the $\mathrm{N}$-gain analysis was carried out. Indicators make the problem solution experience the highest increase, followed by making or realizing projects that have been planned and linking the topic of Covid-19 mitigation with possible disciplines. 


\section{CONCLUSION}

The findings generated in this research are based on the analysis of the data obtained, that the application of project-based learning is able to improve students' reasoning. Although the research conducted by researchers, there are still limitations. The researcher only used 30 students / 1 class from all classes at SMPN 1 Maduran, so that the results of this study may not be generalized to more research subjects.

\section{RECOMMENDATION}

We necessary to suggest for further researchers, in the learning process they should pay attention to the absorption and comprehension power of students, and teachers should be able to make good use of time allocations and use varied methods according to the subject being studied.

\section{ACKNOWLEDGMENT}

Thanks to all parties involved and helping this research can be resolved, especially to SMPN 1 Maduran who was willing to be involved in this research and all class VII-A students who were willing to be research subjects.

\section{REFERENCES}

Ariawan, I. K. E., Sujana, I. W., \& Putra, I. K. A. (2016). Penerapan Pendekatan Saintifik Seting Discovery Learning Berbantuan Media Audio-Visual Meningkatkan Kompetensi Pengetahuan IPS dan Penalaran. MIMBAR PGSD Undiksha, 4(1).

Bransford, J., and B.S. Stein. 1993. The IDEAL Problem Solver: A Guide for Improving Thinking, Learning, and Creativity (2nd ed). New York: W.H. Freeman.

Depdiknas. 2008. Panduan Pengembangan Bahan Ajar SMA. Jakarta: Depdiknas.

Fatharani, Atika. (2019). Pengembangan Lembar Kerja Siswa (LKS) dengan Model Problem Solving untuk Melatihkan Penalaran Siswa pada Materi Tekanan. Skripsi Tidak Diterbitka. Surabaya: Universitas Negeri Surabaya.

Hadi, Windia. 2016. "Meningkatkan Kemampuan Penalaran Siswa SMP melalui Pembelajaran Discovery dengan Pendekatan Saintifik". Jurnal Pendidikan Matematika. Vol I. No 1.

Handayani, G. A., Windyariani, S., \& Pauzi, R. Y. (2020). Profil Tingkat Penalaran Ilmiah Siswa Sekolah Menengah Atas Pada Materi Ekosistem:(Profile Of The Level Of Scientific Reasoning Of High School Student On Ecosystem Material). BIODIK, 6(2), 176-186.

Hasanah, U. 2015. Jurnal Pendidikan Kimia. 4(1): 68-73.

John W. Thomas, P. D. (2000). a Review of Research on Project Based Learning. Bob Pearlman, former President of the Autodesk Foundation, 1-49.

Kamdi, Waras. 2007. Pembelajaran Berbasis Proyek: Model Potensial untuk Peningkatan Mutu Pembelajaran, (Online), (Tersedia: http://lubisgrafura.wordpress.com diakses 18 Februari 2020).

Kamdi, Waras. 2008. Pembelajaran Berbasis Proyek: Pendekatan Pembelajaran Inovaif. Malang: Universitas Negeri Malang.

Khoeriyah, D. A. N., \& Ahmad, A. (2020). Penerapan Model Pembelajaran Problem Solving Dengan Pendekatan Saintifik Pada Kemampuan Penalaran Matematis Siswa Kelas VIII B SMP Negeri 1 Padamara. AlphaMath: Journal of Mathematics Education, 6(1), 6267.

Kilpatrick, J. et al. (2001). Adding it up: Helping Children Learn Mathematics, (Online), (Tersedia: http://bookzz.org diakses 21 Februari 2020).

Keputusan Menteri dalam Negeri Nomor 131 Tahun 2003 Tentang Pedoman Penanggulangan Bencana Penanganan Pengungsi di Daerah. 
Lamapaha, Y. F. (2017). Pengembangan lembar kerja siswa berbasis kontekstual berorientasi penalaran saintifik. Jurnal Pendidikan Matematika dan Sains, 5(1), 121597

Mazfufah, N. F. (2017). Pengaruh metode diskusi isu-isu sosiosaintifik terhadap kemampuan penalaran ilmiah peserta didik (Bachelor's thesis, fitk).

Munir, M. (2019). Strategi Guru dalam Problem Based Learning untuk Meningkatkan Penalaran Matematika Siswa. De Fermat: Jurnal Pendidikan Matematika, 2(2), 103108

Nurmaliyani, N. (2018). Pembelajaran Berbasis Masalah Erosi Email Gigi Untuk Meningkatkan Kemampuan Penalaran dan Keterampilan Proses Sains Siswa.

Ntelok, I. F., Sudria, I. B. N., \& Suja, I. W. (2018). Pengembangan Perangkat Pembelajaran Saintifik Dengan Model Pembelajaran Problem Solving Melalui Penalaran Deduktif Pada Topik Laju Reaksi. Jurnal Pendidikan Kimia Undiksha, 2(1), 28-39.

Pelamonia, J. (2016). Penalaran Saintifik Dan Perubahan Konseptual (Studi Cross-sectional Pada Pembelajaran IPA Biologi Siswa SD, SMP, SMA di Kota Ambon). DISERTASI dan TESIS Program Pascasarjana UM.

Permatasari, N. (2019). Penalaran Imitatif dan Kreatif Matematis Siswa Yang Mengikuti Pembelajaran Model Problem-Based Learning Dengan Pendekatan Saintifik (Doctoral dissertation, Universitas Pendidikan Indonesia).

Prastiwi, V. D., Parno, P., \& Wisodo, H. (2018). Identifikasi pemahaman konsep dan penalaran ilmiah siswa SMA pada materi fluida statis. Momentum: Physics Education Journal.

Rahayu, Yubhanir Muji. 2017. Profil Kemampuan Penalaran Siswa SMP dalam Menyelesaikan Masalah Ditinjau dari Kepribadian Introvert dan Extrovert pada Materi Kalor. Skripsi Tidak Diterbitkan. Surabaya: Universitas Negeri Surabaya.

Septaria, K., Dewanti, B. A., \& Habibbulloh, M. (2019). Implementasi Metode Pembelajaran Spot Capturing Pada Materi Pemanasan Global untuk Meningkatkan Keterampilan Proses Sains. Prisma Sains: Jurnal Pengkajian Ilmu dan Pembelajaran Matematika dan IPA IKIP Mataram, 7(1), 27-37.

Septaria, K. (2019). Mengeksplorasi Argumentasi dan Pengetahuan Pendidik Ilmu Pengetahuan Alam (IPA) Tentang Pemanasan Global [Exploring the Arguments and Knowledge of Natural Sciences (IPA) Educators on Global Warming]. PEDAGOGIA: Jurnal Pendidikan, 8(2), 247-256.

Sudria, I. B. N., Wiratma, I. G. L., \& Sembiring, L. K. B. (2019). Pengembangan Perangkat Pembelajaran Saintifik Dengan Model Problem Based Learning Melalui Penalaran Induktif Pada Topik Laju REAKSI. Jurnal Pendidikan Kimia Indonesia, 3(1), 32-45.

Shofiyah, N., \& Wulandari, F. E. (2018). Model problem based learning (PBL) dalam melatih scientific reasoning siswa. Jurnal Penelitian Pendidikan IPA, 3(1), 33-38.

Undang-undang Republik Indonesia No. 20 Tahun 2003. Sistem Pendidikan Nasional. Jakarta: Departemen Pendidikan Nasional Republik Indonesia.

Yulianti, E., \& Zhafirah, N. (2020). Peningkatan Kemampuan Penalaran Ilmiah Siswa Sekolah Menengah Pertama Melalui Model Pembelajaran Inkuiri Terbimbing. Jurnal Penelitian Pendidikan IPA, 6(1), 125-130. 